\title{
LUMINESCENCE AND RADIOCARBON DATING AS TOOLS FOR THE RECOGNITION OF EXTRATERRESTRIAL IMPACTS
}

\author{
WOJCIECH T. J. STANKOWSKI \\ Higher School of Economy (WSG), Garbary 2, 85-229 Bydgoszcz; \\ Adam Mickiewicz University, IG, Maków Polnych 16, 61-606 Poznań;
}

Received 22 April 2010

Accepted 15 October 2010

\begin{abstract}
Extraterrestrial events and the extraterrestrial origin of both material and impact forms were recognized in the Morasko, Kaali and Przełazy shallow geological profiles by means of luminescence and radiocarbon dating as well as the frequency of magnetic spherules. The obtained results provide a promising tool for proving theat extraterrestrial events affected characteristic lithological and morphological environmental features.
\end{abstract}

Keywords: impacts, luminescence dating, radiometric dating.

\section{INTRODUCTION}

Extraterrestrial matter continuously reaches the Earth system: every 24 hours, 7-9 specimens larger than $10 \mathrm{~cm}$ fall on our planet (2500-3200 meteorites per year). Micrometeorites and cosmic dust constitute the bulk of the extraterrestrial material reaching the Earth surface (Brownlee et al. 1996). The mass of the material reaching the Earth is not precisely known, but estimates range from a symbolical amount of 5-10 $\mathrm{kg}$ per day to as much as 1200 tonnes per day. These differences are well illustrated by the estimates contained in Pokrzywnicki (1971), Ceplecha (1992), Thompson (1996), Peucker-Ehrenbrink (1996) and Hurnik and Hurnik (2005). The delivery of extraterrestrial material, though occurring continuously, occurs in "pulses" in both space and time.

The extraterrestrial matter reaching the Earth surface is reflected in both the topography (the bolides and meteorites create craters) and the sandy/silty fractions of micrometeorites and cosmic dust that become embedded in the Earth's strata. The craters are commonly quickly eroded or filled by mineral/organic deposits, and thus

Corresponding author: W. T. J. Stankowski

e-mail: stawgeo@amu.edu.pl disappear from the landscape. It is therefore, as a rule, practically impossible to trace such craters morphologically. As a consequence, oblique methods of recognition of such morphogenetic events should be applied. The search for, and analysis of, the fine-grained extraterrestrial material may provide a practical tool, although the fine and finest particles become strongly dispersed in the mineral sediments. Extraterrestrial particles may, however, be isolated relatively easily from organic sediments such as peat and gyttja.

Such a lithological and mineralogical approach, in combination with so-called absolute dating, seems to be a suitable tool for the recognition of both fresh and 'fossil' particles derived from extraterrestrial events.

\section{THE LUMINESCENCE INDICATORS OF EX- TRATERRESTRIAL EVENTS}

Explosive meteorite impacts generate thermal effects in their surroundings which are reflected by zeroing of the luminescence of quartz grains. This has been documented in detail for prehistoric impacts near Morasko (Poland) and Kaali (Estonia), where hot lumps of meteorite material fell on unconsolidated sediments, penetrated 
them and caused bleaching of the material and development of a sinter-like coating around the large lumps. Later weathering resulted in the formation of a compact crust (Stankowski 2005, 2008, Stankowski et al., 2007).

This distinctive, thermally induced coating around iron meteorites was found on every Morasko fragment. The TL dates obtained for these fragments were found to differ little from one another (Table 1) and indicate a luminescence zeroing time of about 5000-6000 years ago.

The luminescence age determinations of the meteorite coatings were placed in a wider perspective by the study of the mineral sediments inside the Morasko impact craters. The unconsolidated Neogene rocks (the so-called "Poznań Series") are several millions of years old and the Quaternary sediments, mainly from the Early and Middle Pleistocene, (with a small proportion of sediments from the last glaciation, the "Poznań Phase") are not younger than 18,000-17,000 years BP. The results of luminescence dating suggest, however, a younger bleaching of the material (partly completely reset by substantial bleaching and partly incompletely by less intensive exposure to the increased temperature and pressure). The 101 grains of which the age was determined (Table 2 and Fig. 1) indicate that about $43 \%$ of them were zeroed less than 10,000 years ago $(\sim 13 \%<5000$ years and $\sim 30 \%$ in the $5,000-10,000$ years range), and that $19 \%$ were zeroed between 10,000 and 15,000 years ago. Some $10 \%$ of the datings indicate an age of 15,000-20,000 years ago, reflecting the time of the maximum extent of the last glacial (Poznan Stage). The remaining grains $(28 \%$ - the real numbers of data $=29$ ) indicate ages of more than 20,000 years. Some $14 \%$ of the results lie between 20,000 and 50,000 years, and another $14 \%$ indicate ages in excess of 50,000 years (one of them even 200,000 years). It is important, however, to note here that the quartz grains from the bottom of depressions A and B show the youngest bleaching. This strongly suggests that the depressions were created relatively recently, most probably as a consequence of the impact.

The Kaali impact took place in lithified Silurian dolomite with a very thin Quaternary cover (not younger than 10,000 years). Two samples from the small crater no. 4 (a depression at the site of the meteorite impact) were dated: one from a depth of $20 \mathrm{~cm}$ under the Quaternary (powdered rock) and a second one from $70-78 \mathrm{~cm}$ deep (less destroyed strata). The first sample gave an age

Table 1. $T L$ ages of the Morasko meteorite coatings, reflecting the time of zeroing. The dating was performed in the Institute of Geography of Gdańsk University by Dr hab. Stanisław Fedorowicz (Stankowski et al., 2007).

\begin{tabular}{lcccc}
\hline & \multicolumn{4}{c}{ meteorite } \\
\cline { 2 - 5 } & $\mathbf{1}(164 \mathrm{~kg})$ & $\mathbf{2}(11 \mathrm{~kg})$ & $\mathbf{3}(10.5 \mathrm{~kg})$ & $\mathbf{4}(21 \mathrm{~kg})$ \\
\hline age (ka) & $5.2 \pm 0.9$ & $5.0 \pm 0.7$ & $4.7 \pm 0.4$ & $6.1 \pm 0.7$ \\
\hline $\begin{array}{l}\text { laboratory } \\
\text { number }\end{array}$ & UG-5941 & UG-5942 & UG-5943 & UG-5944 \\
\hline
\end{tabular}

of $\sim 5400 \pm 600$ years BP (UG 5915), whereas the second sample yielded $\sim 65,000 \pm 5,000$ years (UG 5919). It can thus be assumed that the pressure-induced shock waves and the temperature decreased with depth (Table 3). Both dates are dramatically inconsistent with the Silurian age of the dolomite and must be attributed to a much later zeroing of the strata.

Two other samples, taken from the rim top of the main Kaali crater (which is built of a mixture of Quaternary and fragmented Silurian strata) have given results of $5600 \pm 900$ (UG 5914) and $5800 \pm 600$ (UG 5913) years BP (Table 3). Also dates from a number of small craters (Table 3 ) in the surroundings show a young zeroing event: the craters no. $2 / 8$ gave $4250 \pm 320$ (GdTL 878) years BP, and $8700 \pm 780$ (GdTL 879) and $9800 \pm 2300$ (UG 5918) years BP as age, respectively, whereas crater no. 1 yielded $5800 \pm 600$ (UG 5916) and $11,400 \pm 2,600$ (UG 5917) years BP.

Reworked material infilling crater no. 7 gave $\sim 7,160 \pm 410$ (GdTL 927) and 7090 \pm 340 (GdTL 928) as ages, with one additional date of 10,200 \pm 460 (GdTL 929) years BP (Table 3; see also Raukas and Stankowski, 2010). There can consequently be no doubt about the postdepositional zeroing of the sediments, which must be attributed to the impact events. The present author's conclusion is that the dates of $\sim 7000$ years BP indicate the time of the crater infillings, which happened almost immediately after the craters' creation (Raukas and Stankowski, 2010). The third, higher age for the thin layer of silty-loamy sediments (mainly $2-3 \mathrm{~cm}$ thick, occasionally up to $10 \mathrm{~cm}$ ) situated at the profile bottom, immediately

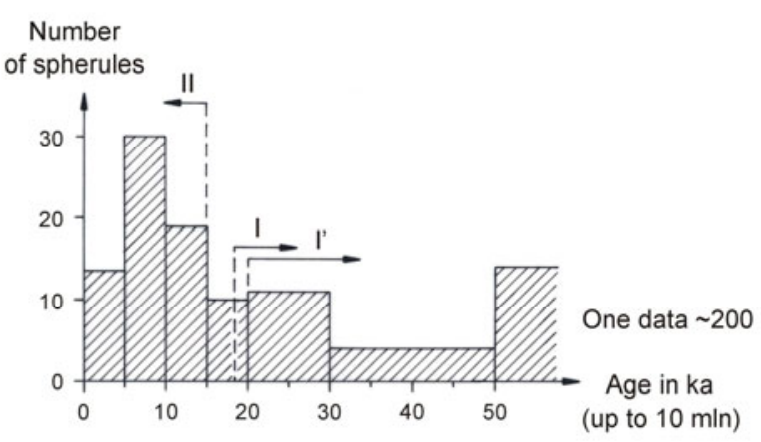

Fig. 1. Age measurements from the bottom of the Morasko craters $A$ and $B(n=101)$

Table 2. Measurements of the OSL age of the 101 samples from the bottom of craters A and B in the "Meteoryt Morasko" Reserve. Study conducted by Prof. Dr Andrzej Bluszcz (GADAM Centre of Excellence, Institute of Physics, Silesian University of Technology).

\begin{tabular}{cccccccc}
\hline & \multicolumn{6}{c}{ age range (× 1000 years) } \\
\cline { 2 - 8 } & $<5$ & $5-10$ & $10-15$ & $15-20$ & $20-30$ & $30-50$ & $>50$ \\
\hline number of grains & 13 & 30 & 19 & 10 & 11 & 4 & 14 \\
\hline
\end{tabular}


on top of the Silurian dolomite might originate from "contamination" of these strata by older material. This is probably similar to the case for the results presented in Stankowski et al. (2007).

Table 3. Luminescence ages (TL and OSL) of samples from the Kaali craters. The datings were performed at the GADAM Center of the Institute of Physics, Silesian University of Technology, under supervision of Prof. Dr A. Bluszcz, and at the Institute of Geography of Gdańsk University by Dr hab. S. Fedorowicz.

\begin{tabular}{|c|c|c|c|}
\hline \multirow[t]{2}{*}{ sample position } & \multicolumn{2}{|c|}{$\begin{array}{c}\text { age ranges } \\
(\times 1000 \text { years })\end{array}$} & \multirow[t]{2}{*}{ _remarks } \\
\hline & TL & OSL & \\
\hline \multicolumn{4}{|l|}{$\begin{array}{l}\text { striking niche of } \\
\text { crater } 4 \text { bottom }\end{array}$} \\
\hline $\begin{array}{l}\text { depth } \sim 20 \mathrm{~cm} \\
\text { depth } \sim 55 \mathrm{~cm}\end{array}$ & $5.4 \pm 0.6$ & 1.55 (?) & $\begin{array}{l}\text { powdered dolomite } \\
\text { weakly consolidate }\end{array}$ \\
\hline & & & dolomite \\
\hline depth $70-78 \mathrm{~cm}$ & $65 \pm 5$ & & $\begin{array}{l}\text { weakly consolidate } \\
\text { dolomite }\end{array}$ \\
\hline \multirow{2}{*}{$\begin{array}{l}\text { top part of main } \\
\text { crater rim }\end{array}$} & $5.6 \pm 0.9$ & & \multirow{2}{*}{$\begin{array}{l}\text { mixture of Quaternary } \\
\text { sediments and frag- } \\
\text { mented Silurian rocks }\end{array}$} \\
\hline & $5.8 \pm 0.6$ & & \\
\hline $\begin{array}{l}\text { proximal part of } \\
\text { the rim of crater } 1\end{array}$ & $\begin{array}{c}5.8 \pm 0.9 \\
11.4 \pm 2.6\end{array}$ & & $\begin{array}{l}\text { mixture of Quaternary } \\
\text { sediments and frag- } \\
\text { mented Silurian rocks in } \\
\text { between uplifted blocks } \\
\text { of Silurian strata }\end{array}$ \\
\hline \multirow{2}{*}{$\begin{array}{l}\text { top part of the rim } \\
\text { of crater } 2 / 8 \text {, }\end{array}$} & & & \multirow{3}{*}{$\begin{array}{l}\text { mixture of Quaternary } \\
\text { sediments and frag- } \\
\text { mented Silurian rock; } \\
\text { Quaternary sediments }\end{array}$} \\
\hline & $9.8 \pm 2.3$ & & \\
\hline $\begin{array}{l}20 \text { m outside the } \\
\text { rim }\end{array}$ & & $4.25 \pm 0.32$ & \\
\hline \multirow{3}{*}{ infillings of crater 7} & & $\begin{array}{l}7.10 \pm 0.41 \\
7.00 \pm 0.34\end{array}$ & $\begin{array}{l}\text { mixture of Quaternary } \\
\text { sediments and frag- }\end{array}$ \\
\hline & & & mented Silurian rock; \\
\hline & & 10 & $\begin{array}{l}\text { thin silty-loamy sedi- } \\
\text { ments }\end{array}$ \\
\hline
\end{tabular}

Only two Kaali luminescence dates (11.4 and $10.2 \mathrm{ka})$ are almost contemporaneous with the Pandivere - Palivere stadials (Raukas and Stankowski, 2005; 2010). This can be explained by incomplete bleaching of the material, or even the absence of zeroing, as well by the influence of contamination by other strata, as suggested before. The rest of the dates gave a mean value 6.1-6.6 ka, which indicates most probably the time of the Kaali meteorite impact.

\section{THE RADIOCARBON INDICATORS OF EX- TRATERRESTRIAL EVENTS}

Apart from the luminescence analyses, radiocarbon dating turns out to be a good tool for recognising extraterrestrial matter in Quaternary sediments and also for determining the age of meteorite craters. This is well demonstrated by the ${ }^{14} \mathrm{C}$ analyses carried out at the Morasko impact site and its surroundings, as well as at the Przełazy site (not every presented radiocarbon dates are calibrated, thus only basic measurement results should be comparison).

The unusually young age of the first sediments in the Morasko symmetrical depressions excludes their origin as cryogenic features. The continuous accumulation in the two largest Morasko depressions started long after possible periglacial conditions and after permafrost degradation. Moreover, the obtained radiocarbon dates indicate a Holocene age - see Table 4: crater A (samples from 3-5 $\mathrm{cm}$ above the mineral bottom and from a $\sim 20 \mathrm{~cm}$ higher level) yielded $4495 \pm 35$ years BP (Poz-18863; 49805300 cal. BP), and $4465 \pm 35$ years BP (Poz-18864, 4970-5290 cal BP), respectively; crater B (sample from $3-5 \mathrm{~cm}$ above the mineral bottom) was dated at $4760 \pm 40$ years BP (Poz-18960; 5320-5600 cal. BP). It should be added that the results of these radiocarbon dates corre-

Table 4. The radiocarbon ages of samples from Morasko depressions and Szlaban site. Data from bottom part of organic infillings of craters A, B and Szlaban site, determined at the Poznań Radiocarbon Laboratory, by Prof. T. Goslar and Morasko crater F, determined at the GADAM Centre of Excellence, Institute of Physics, Silesian University of Technology, by Prof. A. Pazdur.

\begin{tabular}{|c|c|c|c|c|}
\hline Morasko craters and Szlaban site & Sample position & Lab. co. & $\begin{array}{c}{ }^{14} \mathrm{C} \text { age } \\
\text { (BP) }\end{array}$ & $\begin{array}{c}\text { Cal age (BP) } \\
95.4 \% \text { conf. int. }\end{array}$ \\
\hline Morasko crater: & $\mathrm{cm}$ above the mineral bottom & & & \\
\hline A & $\begin{array}{l}\sim 20 \mathrm{~cm} \\
3-5 \mathrm{~cm}\end{array}$ & $\begin{array}{l}\text { Poz-18864 } \\
\text { Poz-18663 }\end{array}$ & $\begin{array}{l}4465 \pm 35 \\
4495 \pm 35\end{array}$ & $\begin{array}{c}4970-5290 \\
4980-5000(1.2 \%) \\
5030-5310(94.2 \%)\end{array}$ \\
\hline B & $3-5 \mathrm{~cm}$ & Poz-18960 & $4760 \pm 40$ & $\begin{array}{l}5320-5380(14.1 \%) \\
5440-5590(81.3 \%)\end{array}$ \\
\hline $\mathrm{F}$ & $\begin{array}{l}\text { Organic interbeding layer at } \\
\text { the depth } 190-200 \mathrm{~cm}\end{array}$ & Gd-10894 & $3360 \pm 100$ & $3380-3850$ \\
\hline Szlaban site & $\begin{array}{l}\text { Kettle-hole organic infilling, } \\
\text { depth: } \\
\quad 80 \mathrm{~cm} \\
90 \mathrm{~cm}\end{array}$ & $\begin{array}{l}\text { Poz-7004 } \\
\text { Poz-7005 }\end{array}$ & $\begin{array}{l}4750 \pm 40 \\
5070 \pm 40\end{array}$ & $\begin{array}{c}5320-5390(19.2 \%) \\
5440-5590(76.2 \%) \\
5720-5920\end{array}$ \\
\hline
\end{tabular}

* The calibration was conducted using OxCal v.3.10 programme (Bronk Ramsey 1995, 2001) and calibration curve IntCa109 (Reimer et al., 2009) 
spond very well with the palynological estimates, since the calibrated dates are consistent with the interpretations of Tobolski (1976). In one of the smaller depressions (number F), two thin, discontinuous layers of organic sediment are present within the crater mineral infilling. The oldest one is situated at a depth of $190-200 \mathrm{~cm}$ and gave a radiocarbon age of $3360 \pm 100$ (Gd-10894, 33803850 cal BP). The ${ }^{14} \mathrm{C}$ dates are compatible with the luminescence dates mentioned above. The genesis of the Morasko depressions as a result of an impact thus seems to be proven.

Each large meteor shower seems to be connected with the falling of fine particles (micrometeorites, cosmic dust and spherules) which are relatively easy to find in peat bogs. It should be noticed in this context that a layer rich in metallic spherules has been found at a depth of $\sim 80-90$ $\mathrm{cm}$ in a peat bog at the Szlaban site near Oborniki (approx. $30 \mathrm{~km}$ north of Morasko - see Table 4), which is situated under the reconstructed trajectory of the Morasko meteorite (Hurnik, 1976). Radiocarbon dates of this spherules-rich peat layer are $4750 \pm 40$ (Poz-7004, 5320-5590 cal BP) to $5070 \pm 40$ (Poz-7005, 5720-5920 cal BP) years BP. This is consistent with the dating of the Morasko meteorite shower as more than $5000 \mathrm{cal}$ BP.

The creation of the famous crater in Ilumetsa (Estonia) was dated thanks to investigation of the fine magnetic material in a particular organic layer in a neighbouring peat bog (Liiva et al., 1979, Raukas et al., 2001).

The promising results of the investigation of the fine magnetic material from Ilumetsa and the Morasko neighbourhood were a reason to carry out similar investigations around Przełazy (western Great Polish Lowland). The Przełazy meteorite, weighing around $102 \mathrm{~kg}$, was found a few years before 1847 by a farmer digging a drainage ditch in a "damp meadow" in the direction of the nearby lake. The place and time of the fall are not known. An attempt to find the answers to both questions was made by collecting spherules from the nearest peat bogs and from the mineral surface of the surroundings of Przełazy (Stankowski and Uścinowicz, in press). The principal study area was the peat bog immediately southwest of the settlement. Several sections were investigated; two of them are shown in Fig. 2. One represents an open peat-bog, and the second is from the bog's margin where the peaty condensed sediments have a sandygravely-stony cover. In the topmost parts of both profiles numerous magnetic spherules were found. Most probably they form a mixture of extraterrestrial and manmade spherules. The upper and middle parts of the compacted peat contain only isolated spherules, as in the middle part of the open peat-bog section. The bottom part of the organic sediments and the upper part of the underlying mineral material enriched in organic matter contain magnetic spherules with strongly varying chemical compositions.

Soil profiles from the bank of the peat bog (where the largest number of spherules was found) and the northern foreland yielded magnetic spherules as well. This strongly suggests a trajectory of the Przełazy meteorite from the north-west, and an impact somewhere in the nearest peat bog, at a small distance SW of the village.

Therefore, according to the present author's opinion, the impact of the Przełazy meteorite most likely coincided with the growth of the bottom peat level in which a significantly increased concentration of magnetic material is present. The impact should thus be dated as between the Late Glacial and the Holocene, probably the early Holocene $(11,000-9,000$ years BP).

\section{CONCLUSIONS}

The luminescence and radiocarbon age determinations of the Morasko impact are complementary and consistent. All dates from Morasko, Przełazy and Kaali, in combination with the occurrence of extraterrestrial matter in superficial sediments, form a good indicator for impacts and explain the origin of the craters.

The results indicate that the approach applied during the analysis of the three impacts mentioned above provides a promising tool for proving that extraterrestrial events affected specific lithological and morphological features.

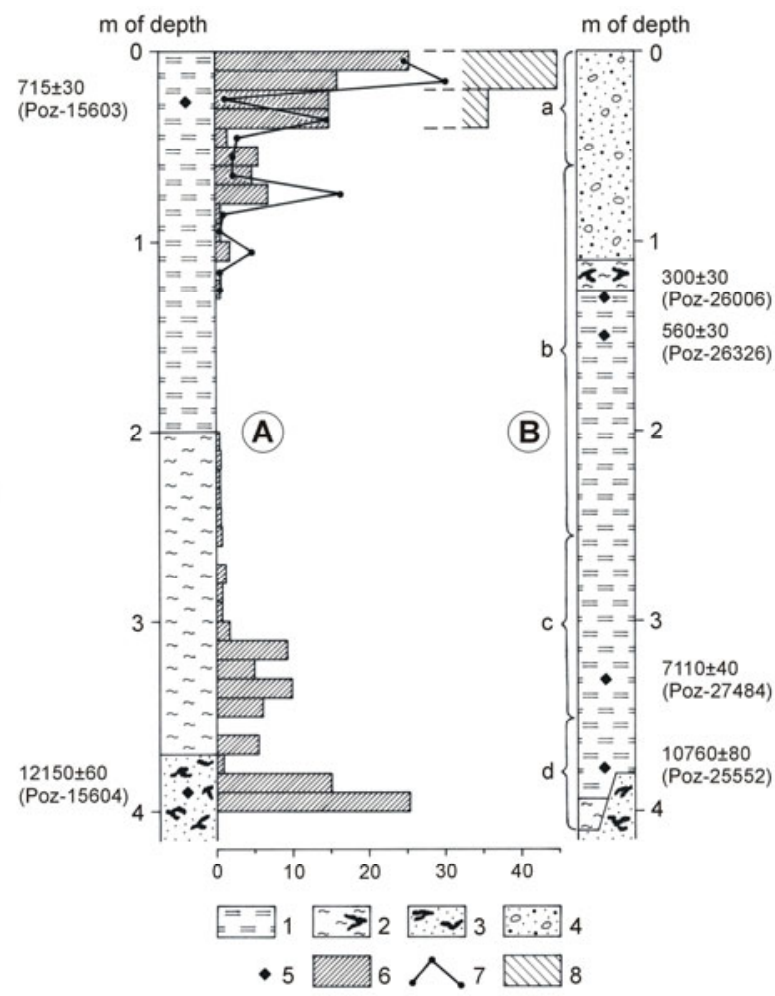

Fig. 2. Peat-bog sections from the SW neighborhood of Przełazy and magnetic spherules found in them 


\section{ACKNOWLEDGEMENTS}

I express my particular gratitude to Prof. A. Raukas from the Geological Institute, Tallinn Technical Umiversity; Prof. A. Bluszcz from the Institute of Physics of the Silesian University of Technology; Prof. T. Goslar from the Poznań Radiocarbon Laboratory; as well as the M.Sc. students T. Jopek, A. Filipek and Ph.D student G. Uścinowicz from the Geological Institute of Adam Mickiewicz University. Language correction was done by Prof. Tom van Loon.

\section{REFERENCES}

Bronk Ramsey C, 1995. Radiocarbon calibration and analysis of stratigraphy: the OxCal program. Radiocarbon 37(2): 425-430.

Bronk Ramsey C, 2001. Development of the radiocarbon calibration program. Radiocarbon 43(2A): 355-63.

Brownlee DE, 1996. The elemental composition of interplanetary dust. Astronomical Society of the Pacific Conference Series. 104: 161184

Ceplecha Z, 1992. Influx of interplanetary bodies onto Earth. Astronomy \& Astrophysics 263: 361-366

Hurnik H, 1976. Meteorite Morasko and the region of its fall. Wydawnictwo Naukowe UAM, Poznan: 64 pp.

Hurnik B and Hurnik H, 2005. Materia kosmiczna na Ziemi, jej źródła $i$ ewolucja (Cosmic matter on the Earth, its sources and evolution). Wydawnictwo Naukowe UAM, Poznań: 282 pp (in Polish).

Liiva A, Kassel H and Aaloe A, 1979. The age of Ilumetsa craters. Estonian Nature 12: 762-764

Peucker-Ehrenbrink B, 1996. Accretion of extraterrestrial matter during the last 80 million years and its effect on marine osmium-26 in individual cosmic spherules from Matarctica. Meteoritics 30: 728732

Pokrzywnicki J, 1971. O ilości spadającej na Ziemię materii kosmicznej (The amount of cosmic matter falling into Earth). Acta Geophysica Polonica XIX: 439-444 (in Polish)
Raukas A., Tiirmaa R., Kaup E., Kimmel K., 2001. The age of the Ilumetsa meteorite craters in South-East Estonia. Meteorites and Planetarny Science 36(11): 1507-1514, DOI 10.1111/j.19455100.2001.tb01842.x.

Raukas A and Stankowski W, 2005. Influence of sedimentological composition on OSL dating of glacifluvial deposits: example from Estonia. Geological Quarterly 49: 463-470

Raukas A and Stankowski W, 2010. The Kaali crater field and other geosites of Saaremaa Island (Estonia): the perspectives for a geopark. Geologos 16 (in press).

Reimer PJ, Baillie MGL, Bard E, Bayliss A, Beck JW, Blackwell PG, Bronk Ramsey C, Buck CE, Burr G, Edwards RL, Friedrich M, Grootes PM, Guilderson TP, Hajdas I, Heaton TJ, Hogg AG, Hughen KA, Kraiser KF, Kromer B, McCormac FG, Manning S, Reimer RW, Richards DA, Southon JR, Talamo S, Turney CSM, van der Plicht J, Weyhenmeyer CE, 2009. IntCal09 and Marine09 radiocarbon age calibration curves, $0-50,000$ years cal BP. Radiocarbon 51: 1111-1150.

Stankowski WTJ, 2005. Luminiscence as a tool of impact craters recognition. Presentation at the Workshop in Stubice "Landscape development in central European Lowland during past 25000 years", organized by Adam Mickiewicz University Poznań / GeoForschungsZentrum Potsdam / Brandenburg University of Technology.

Stankowski WTJ, 2008. Meteoryt Morasko, osobliwość obszaru Poznania; Morasko (Meteorite, a curiosity of the Poznań region). Wydawnictwo Naukowe UAM, Poznań: 94 pp.

Stankowski WTJ, Raukas A, Bluszcz A and Fedorowicz S, 2007. Luminescence dating of the Morasko (Poland), Kaali, Ilumetsa, Tsoorikmae (Estonia) meteorite craters. Geochronometria 28: 2529, DOI 10.2478/v10003-007-0031-0.

Stankowski WTJ and Uścinowicz G (in press). The age of the Przełazy (Seeläsgen) meteorite fall in the light of the metallic spherules content in shallow geological profiles. Acta Geologica Polonica.

Tobolski K, 1876. Palynological investigations of bottom sediments in closed depressions. In: Meteorite Morasko and the region of the fall of the meteorite. Wydawnictwo Naukowe UAM, Poznań: 2126

Thompson T, 1996. Meteorite dust and the age of the Earth. The Talk. Origins Archive http:/www.talkorigins.org/faqs/moon-dust.html, [last update: September 5, 1996] 